\title{
Experimental Study of Learning Methods toward Students Learning Outcomes Viewed from Gender, Motivation, and Self-Efficacy
}

\author{
Urip Tisngati ${ }^{1}$, Martini $^{2}$, Nely Indra Meifiani ${ }^{3}$, Dwi Cahyani Nur Apriyani ${ }^{4}$ \\ STKIP PGRI Pacitan, Pacitan, Indonesia \\ \{ifedeoer@gmail.com ${ }^{1}$, oing65@gmail.com ${ }^{2}$, indrameifiani@yahoo.co.id ${ }^{3}$, \\ yaa_latiif@yahoo.com $\left.{ }^{4}\right\}$
}

\begin{abstract}
This research aims to test five research hypotheses, related to different students' outcomes test based on four factors: learning methods, gender, motivation and self-efficacy as well as the interaction among factors to independent variable. This research was experimental method study by implementing $2 \times 2 \times 2 \times 2$ factorial design. Each factor consists of two levels. The populations were the seventh grade of junior high school students in Donorojo sub district with 206 students consisting 111 male students and 95 female students. The data were selected by using cluster random sampling. Normality and homogeneity test which taken from students mid examination score were implemented before doing t-test for balance test. The final data were obtained from the final test scores of mathematics learning on probability theory material and statistical material for the experimental class (jigsaw cooperative learning method) and control class (conventional method), students gender documents, motivation questionnaire, and self-efficacy questionnaire. Questionnaire and tests were validated by experts and tested for its reliability. The data were analyzed by using two-way variance analysis techniques with SPSS. The results show that: (1) there were no differences in students' mathematics learning outcomes between experimental and control classes, (2) there were no differences in mathematics learning outcomes between male and female students, (3) there were no differences in mathematics learning outcomes between students with high and low motivation, (4) there are differences in students' mathematics learning outcomes between high and low self-efficacy, and (5) there is no interaction between learning methods, gender, motivation, and self-efficacy towards mathematics learning outcomes.
\end{abstract}

Keywords: Learning Methods, Learning Outcomes, Gender, Motivation, SelfEfficacy

\section{INTRODUCTION}

An optimal learning outcome is one of learning objectives for students in formal education. It means that the students deal with various subjects' material based on their grade and curriculum. The students learning outcomes indicators are measured by using a series of learning outcome test that show the students' progress score or students achievement during a period of time [1]. There are various alternative evaluation techniques for measuring learning outcomes used by teachers, schools, researchers, and government fit to their goals. Students 
competency tests were used to find out student learning outcomes after following learning process on certain materials and periods, such as the Mid Examination and Final Semester Examination.

The results become learning program evaluation for students, teachers, schools and government as in National Examination (UN). National Examination (UN) is conducted to monitor, encourage and improve the quality of learning [2]. The success of teachers and schools can be seen from the good average result of students' outcome or vice versa. Learning achievement is a success evidence of students learning process [3]. Learning outcome itself becomes a concern for education doers, including in Indonesia. This phenomenon encourages each educational institution to compete to show its excellence by managing variables that can improve student-learning outcomes.

However, yearly student-learning outcomes, such as the National Examination results have to be noticed because it shows decreasing results. Based on Statistics of 2016/2017 National Examination Results [2], the National Examination average in 2017 is 54.25 while the average in 2016 is 58.61. This happens due to the increasing integrity of $2017 \mathrm{UN}$ implementation.

\section{LITERATURE REVIEW}

There are two factors that give effect to student learning outcomes including mathematics subjects, namely internal factors and external factors. Internal factors consist of intellectual, mental, and physical conditions while external factors consist of family, school, environment, and society factors [4]. This result becomes the considerations for researchers and practitioners to be the subject of discussion, study and research by various education experts and practitioners, including in this study.

Previous studies point out that communication, learning facilities, regulations, and family pressure are factors that influence student achievement [5]. Furthermore, the teacher's experience, family expenses, government expenditure, and the level of morbidity (susceptibility to illness) give significant influence to student outcomes [6]. Some researchers revealed the influence of teacher skills on student outcomes [7], [8], [9] as well as students' cognitive and emotional and social competencies [10]. Other researchers show that teachers and learning give effect on student behavior and attitudes or as affective aspects [11].

Based on this background, this study aims to test the differences of learning methods toward student learning outcomes, especially in mathematics subjects, as well as their interaction with gender factors and students' affective factors including motivation and self-efficacy through experimental research. Previous researchers have examined the correlation between gender and student learning outcomes [12], [13]; the correlation between motivation and learning outcomes [14],[15], the correlation between self-efficacy and learning outcomes [16],[17], the correlation between gender and outcomes motivation [18].

This research used 4-factor factorial design that is different from the previous study. The results of this study are expected to provide theoretical and practical contributions related to experimental design four factors that can influence student-learning outcomes in education.

\section{METHOD}

Viewed from the objectives, the researchers used quantitative research with pseudo experimental methods. Experimental studies, or design research is a good basic of research. It directs the experiment by regulating data collection, defining statistics for the data analysis, and 
guiding the results interpretation [19]. Experimental study or design gives deeper analysis rather than just defining or directing statistical analysis of an experiment.

The steps to construct the experiment are as follows: (1) determining the problem and questions to be tested, (2) defining the population, (3) determining the sampling, and (4) determining the experimental design [20]. This study was quasi-experimental research. In quasiexperimental research, as in experimental research, testing hypothesis was seen as the "intervention" that the evaluated programs or design were tested to know the level of good impact measured by series of decided indicator [21].

The experimental method was chosen because the researchers intended to test four factors design as in design research [22], especially in mathematics education. These four factors acted as the main factor or as an independent variable, including research method, gender, motivation, and self-efficacy factor. Thus, this factorial design study aimed to determine the influence of the main factors toward the dependent variable (learning outcomes) and the interaction factors between the independent variables through experimental studies. Briefly, the factorial design of this research was $2 \times 2 \times 2 \times 2$. Therefore, there were four independent variables (factors) with each factor consisting of 2 levels. For example, the first factor (learning method) has two levels: jigsaw cooperative learning method and conventional learning method (lecturing). The second factor (gender) consists of two levels: male and female students. The third factor (motivation) and the fourth factor (self-efficacy), each consists of two levels: high and low categories. In general, factorial designs are described below.

Table 1. 4 Factorial Design

\begin{tabular}{|c|c|c|c|c|c|}
\hline \multirow{2}{*}{\multicolumn{2}{|c|}{ General Factor }} & \multicolumn{2}{|c|}{ A1 (Jigsaw Method) } & \multicolumn{2}{|c|}{$\mathrm{A}_{2}$ (Conventional Method) } \\
\hline & & $\begin{array}{c}\mathbf{B}_{1} \\
\text { (Male) } \\
\end{array}$ & $\begin{array}{c}\mathbf{B}_{2} \\
\text { (Female) } \\
\end{array}$ & $\begin{array}{c}\text { B }_{1} \\
\text { (Male) }\end{array}$ & $\begin{array}{c}\mathbf{B}_{2} \\
\text { (Female) }\end{array}$ \\
\hline $\begin{array}{c}\mathrm{C}_{1} \\
\mathrm{High}\end{array}$ & $\begin{array}{c}D_{1} \\
\text { High Self- } \\
\text { Efficacy }\end{array}$ & $\mathrm{A}_{1} \mathrm{~B}_{1} \mathrm{C}_{1} \mathrm{D}_{1}$ & $\mathrm{~A}_{1} \mathrm{~B}_{2} \mathrm{C}_{1} \mathrm{D}_{1}$ & $\mathrm{~A}_{2} \mathrm{~B}_{1} \mathrm{C}_{1} \mathrm{D}_{1}$ & $\mathrm{~A}_{2} \mathrm{~B}_{2} \mathrm{C}_{1} \mathrm{D}_{1}$ \\
\hline Motivation & $\begin{array}{c}\mathrm{D}_{2} \\
\text { High Self- } \\
\text { Efficacy }\end{array}$ & $\mathrm{A}_{1} \mathrm{~B}_{1} \mathrm{C}_{1} \mathrm{D}_{2}$ & $\mathrm{~A}_{1} \mathrm{~B}_{2} \mathrm{C}_{1} \mathrm{D}_{2}$ & $\mathrm{~A}_{2} \mathrm{~B}_{1} \mathrm{C}_{1} \mathrm{D}_{2}$ & $\mathrm{~A}_{2} \mathrm{~B}_{2} \mathrm{C}_{1} \mathrm{D}_{2}$ \\
\hline $\begin{array}{c}\mathrm{C}_{2} \\
\text { Low } \\
\text { Motivation }\end{array}$ & $\begin{array}{c}D_{1} \\
\text { High Self- } \\
\text { Efficacy } \\
D_{2} \\
\text { High Self- } \\
\text { Efficacy } \\
\end{array}$ & $\mathrm{A}_{1} \mathrm{~B}_{1} \mathrm{C}_{2} \mathrm{D}_{2}$ & $\mathrm{~A}_{1} \mathrm{~B}_{2} \mathrm{C}_{2} \mathrm{D}_{2}$ & $\mathrm{~A}_{2} \mathrm{~B}_{1} \mathrm{C}_{2} \mathrm{D}_{1}$ & $\mathrm{~A}_{2} \mathrm{~B}_{2} \mathrm{C}_{2} \mathrm{D}_{1}$ \\
\hline
\end{tabular}

Generally, this research procedure includes eleven stages: (1) doing preliminary studies, consisting empirical facts, theoretical studies, as well as previous research studies, (2) identifying the problem, (3) formulating the problem, (4) formulating the research hypothesis, (5) determining population, sample, and sampling, (6) determining data collection techniques, (7) compiling and testing research instruments, (8) collecting data, (9) analyzing data, (10) explaining discussions and conclusions, and (11) ) reporting the results of the study.

This research was conducted for 3 months, started from March-May 2018. The populations of this study were all seventh graders of SMPN 1 Donorojo and SMPN 2 Donorojo, Pacitan, East Java consisting of 206 students, with 111 male students and 95 female students. SMP Negeri 2 Donorojo was chosen because the average score of National Examination in mathematics was the lowest of the three main subjects, 44.21 (2015); 35.18 (2016); and 41.55 
(2017). It also happens in SMP Negeri 1 Donorojo that has low average on National Examination for mathematics subjects 43.81 (2015); 40.04 (2016), and 47.73 (2017). This data were taken from the Ministry of Education and Culture of the Republic of Indonesia. The research sample consisted of one trial class, four classes as an experimental group (94 students), and five classes as a control group (113 students). The sample was selected by using simple random sampling. It means that the data were selected randomly from the population.

As mentioned before, the independent variable consisted of learning method factors (A1 and A2), gender (B1 and B2), motivation (C1 and D2), and self-efficacy (D1 and D2). Furthermore, the dependent variable was the result of students' mathematics learning outcomes. The learning method factor was in the form of interval data measured through students' mathematics learning outcomes data after participating in learning. Gender factor was obtained from documentation techniques. Motivation factors were measured through implementing a questionnaire with 32 questions, and self-efficacy factors were measured by implementing a questionnaire technique with 42 questions. Each research instrument was constructed through five stages: (1) compiling instrument blueprint adapted from theories used, (2) conducting expert validation, (3) testing instruments to trial classes, (4) conducting reliability testing of test instruments / questionnaire by using statistical tools (SPSS), (4) giving instruments to sample classes, both experimental and control classes, (5) analyzing data by using statistical tools.

This research used Jigsaw technique (experimental class) and conventional learning methods (control class). Researchers compiled a learning design containing learning steps based on the method blueprint, then compiled learning outcomes tests on probability theory and statistical material. The two sample classes were previously tested for its balance by using SPSS. The data were taken from Middle Semester Examination score. T-test was used to test the balance after the normality and homogeneity tests. The results were normal and homogeneous.

Self-efficacy questionnaire was constructed from Bandura's (1997) theory, containing three dimensions: level, strength, and generalization dimensions [23]. The level dimension consisted of outcomes motivation, ways of solving problems, and diligence aspects. Strength dimensions contained self-confidence, experience, and self-adjustment aspects. Furthermore, the dimensions of generalization contained cognitive, affective, and behavioral aspects. Based on the results of the reliability test, the questionnaire instrument can be used properly.

After being collected, the data were analyzed by using two-way variance analysis statistical tests using SPSS. As a prerequisite, the data balance test was carried out followed by testing the hypothesis. Two-way variance analysis aimed to examine the effect difference (effect) 4 factors as independent variables including the learning method (factor A), gender (factor B), motivation (factor C), self-efficacy (factor D), and interaction between 4 factor (factor $A B C D$ ) to the dependent variable.

\section{RESULT AND DISCUSSION}

The collected data were analyzed by using two-way ANOVA with SPSS after testing the balance of the initial data from the students' mid examination score previously. The final data are in the form of learning outcomes test scores for two groups after being given the treatment of learning method (A) and controlled by $3 \mathrm{BCD}$ factors (gender, motivation, and self-efficacy). Before testing the hypothesis, normality, homogeneity, and t-test were conducted to test the balance with the following results. 
Table 2. Data Normality Test on Experimental Class by Using Jigsaw Method (A1)

\begin{tabular}{llr}
\hline \multicolumn{3}{c}{ One-Sample Kolmogorov-Smirnov Test } \\
& & Hasil Belajar \\
\hline $\mathrm{N}$ & Mean & 93 \\
Normal Parameters & & 70.67 \\
& Std. Deviation & 12.739 \\
Most Extreme Differences & Absolute & $\mathbf{. 0 9 8}$ \\
& Positive & .087 \\
& Negative & -.098 \\
Kolmogorov-Smirnov Z & & $\mathbf{9 4 8}$ \\
Asymp. Sig. (2-tailed) & & .330 \\
a. Test distribution is Normal. & \\
\hline
\end{tabular}

Based on Table 2, the normality test is performed on each row and column by using nonparametric statistical techniques and the result shows that data A1, A2, B1, B2, C1, C2, D1, D2 are normally distributed. For example, in Table 3 above, the Most Extreme Differences Absolute value is the statistical value for experimental group learning method (A1). The KS test (Kolmogorov-Smirnov) shows the value of .098. It means ( $\mathrm{p}>0.05$ ), or H0 is accepted, so A1 data are normally distributed. Based on the Kolmogorov-Smirnov, $Z$ value is 0.948 . It means that $\mathrm{p}>0.05$, then $\mathrm{H} 0$ is accepted and $\mathrm{A} 1$ data are normally distributed.

Then, the homogeneity test on 4 factors was conducted as the independent variable toward the dependent variable (learning outcomes) by using the Lavene test with the following summary of data.

Table 3. Output Summary of Homogenity Test

\begin{tabular}{cccccc}
\hline Design & $\mathrm{F}$ & $\mathrm{df} 1$ & $\mathrm{df} 2$ & Sig. & Conclusion \\
\hline Intercept + Method & .042 & 1 & 204 & .837 & Same \\
& 3.552 & 1 & 204 & .061 & Same Variation \\
Intercept + Gender & .015 & 1 & 204 & .904 & Same Variation \\
$\begin{array}{c}\text { Intercept }+ \text { Motivation } \\
\text { Intercept }+ \text { Self- }\end{array}$ & .312 & 1 & 204 & .577 & Same Variation \\
Efficacy & & & & & \\
\hline
\end{tabular}

(Data Source: SPSS)

Based on Table 3, same variation is obtained from the value of Sig. $>.05$, that significance value of learning outcomes is based on the independent variable. Then the balance test is implemented as shown in Table 4 below. 
Table 4. Independent Samples Test

\begin{tabular}{|c|c|c|c|c|c|c|}
\hline & & \multicolumn{2}{|c|}{$\begin{array}{c}\text { Levene's Test for Equality of } \\
\text { Variances }\end{array}$} & \multirow[b]{2}{*}{$t$} & \multirow[b]{2}{*}{$d f$} & \multirow[b]{2}{*}{ Sig. (2-tailed) } \\
\hline & & $F$ & Sig. & & & \\
\hline \multirow{2}{*}{ Scores } & $\begin{array}{l}\text { Equal } \\
\text { assumed }\end{array}$ & .042 & .837 & -.455 & 204 & .649 \\
\hline & $\begin{array}{l}\text { Equal variances not } \\
\text { assumed }\end{array}$ & & & -.455 & 196.345 & .650 \\
\hline
\end{tabular}

(Data Source: SPSS)

Based on the output of T-Test Independent Sample, the Sig. (2-tailed) value is .649> .05. It can be concluded that $\mathrm{H} 0$ is rejected. It implies that the average learning outcomes of the experimental group and control group are equal or balance.

After implementing the prerequisite analysis test, the hypothesis is tested. There are 5 hypotheses proposed: (1) there are differences in the effect of learning methods toward student learning outcomes, (2) there are differences in the effect of gender toward student learning outcomes, (3) there are differences in the influence of motivation toward student learning outcomes, (4) there are differences in the effect of self-efficacy toward student learning outcomes, and (5) there is an interaction between learning methods, gender, motivation, and self-efficacy toward learning outcomes. After implementing 2 ways Anava statistical test by using SPSS, the output are as follows:

Table 5. Output Hypothesis Test

Tests of Between-Subjects Effects

Dependent Variable: Learning Outcomes

\begin{tabular}{|c|c|c|c|c|c|}
\hline Source & Type III Sum of Squares & $d f$ & Mean Square & $F$ & Sig. \\
\hline Corrected Model & $3969.270^{\mathrm{a}}$ & 15 & 264.618 & 1.726 & .049 \\
\hline Intercept & 809422.736 & 1 & 809422.736 & $5.281 \mathrm{E} 3$ & .000 \\
\hline Learning_Methods & 65.654 & 1 & 65.654 & .428 & .514 \\
\hline Gender & .097 & 1 & .097 & .001 & .980 \\
\hline Motivation & 590.906 & 1 & 590.906 & 3.855 & .051 \\
\hline Self-Efficacy & 1051.390 & 1 & 1051.390 & 6.860 & .010 \\
\hline $\begin{array}{l}\text { Learning_Methods * } \\
\text { Gender }\end{array}$ & .983 & 1 & .983 & .006 & .936 \\
\hline Learning_Methods $*$ Motivation & 16.012 & 1 & 16.012 & .104 & .747 \\
\hline Learning_Methods * Self-Efficacy & 296.294 & 1 & 296.294 & 1.933 & .166 \\
\hline Gender * Motivation & 30.133 & 1 & 30.133 & .197 & .658 \\
\hline Gender * Self-Efficacy & 4.065 & 1 & 4.065 & .027 & .871 \\
\hline Motivation * Self-Efficacy & 10.419 & 1 & 10.419 & .068 & .795 \\
\hline $\begin{array}{l}\text { Learning_Methods * } \\
\text { Gender * Motivation }\end{array}$ & 2.595 & 1 & 2.595 & .017 & .897 \\
\hline $\begin{array}{l}\text { Learning_Methods * } \\
\text { Gender * Self-Efficacy }\end{array}$ & 61.483 & 1 & 61.483 & .401 & .527 \\
\hline Learning_Methods $*$ Motivation * Efficacy & 169.149 & 1 & 169.149 & 1.104 & .295 \\
\hline Gender * Motivation * Self-Efficacy & 339.727 & 1 & 339.727 & 2.217 & .138 \\
\hline $\begin{array}{l}\text { Learning_Methods * } \\
\text { Gender * Motivation * Self-Efficacy }\end{array}$ & 79.128 & 1 & 79.128 & .516 & .473 \\
\hline Error & 29121.162 & 190 & 153.269 & & \\
\hline Total & 1074805.000 & 206 & & & \\
\hline Corrected Total & 33090.432 & 205 & & & \\
\hline
\end{tabular}




\begin{tabular}{|c|c|c|c|c|c|}
\hline \multicolumn{6}{|c|}{ Tests of Between-Subjects Effects } \\
\hline Dependent Variable: Learning Outcomes & & & & & \\
\hline Source & Type III Sum of Squares & $d f$ & Mean Square & $F$ & Sig. \\
\hline Corrected Model & $3969.270^{\mathrm{a}}$ & 15 & 264.618 & 1.726 & .049 \\
\hline Intercept & 809422.736 & 1 & 809422.736 & $5.281 \mathrm{E} 3$ & .000 \\
\hline Learning_Methods & 65.654 & 1 & 65.654 & .428 & .514 \\
\hline Gender & .097 & 1 & .097 & .001 & .980 \\
\hline Motivation & 590.906 & 1 & 590.906 & 3.855 & .051 \\
\hline Self-Efficacy & 1051.390 & 1 & 1051.390 & 6.860 & .010 \\
\hline $\begin{array}{l}\text { Learning_Methods * } \\
\text { Gender }\end{array}$ & .983 & 1 & .983 & .006 & .936 \\
\hline Learning_Methods $*$ Motivation & 16.012 & 1 & 16.012 & .104 & .747 \\
\hline Learning_Methods * Self-Efficacy & 296.294 & 1 & 296.294 & 1.933 & .166 \\
\hline Gender * Motivation & 30.133 & 1 & 30.133 & .197 & .658 \\
\hline Gender * Self-Efficacy & 4.065 & 1 & 4.065 & .027 & .871 \\
\hline Motivation $*$ Self-Efficacy & 10.419 & 1 & 10.419 & .068 & .795 \\
\hline $\begin{array}{l}\text { Learning_Methods * } \\
\text { Gender* Motivation }\end{array}$ & 2.595 & 1 & 2.595 & .017 & .897 \\
\hline $\begin{array}{l}\text { Learning_Methods * } \\
\text { Gender * Self-Efficacy }\end{array}$ & 61.483 & 1 & 61.483 & .401 & .527 \\
\hline Learning_Methods $*$ Motivation $*$ Efficacy & 169.149 & 1 & 169.149 & 1.104 & .295 \\
\hline Gender $*$ Motivation $*$ Self-Efficacy & 339.727 & 1 & 339.727 & 2.217 & .138 \\
\hline $\begin{array}{l}\text { Learning_Methods * } \\
\text { Gender * Motivation * Self-Efficacy }\end{array}$ & 79.128 & 1 & 79.128 & .516 & .473 \\
\hline Error & 29121.162 & 190 & 153.269 & & \\
\hline Total & 1074805.000 & 206 & & & \\
\hline a. $R$ Squared $=.120($ Adjusted $R$ Squared $=.050)$ & & & & & \\
\hline
\end{tabular}

(Data Source: SPSS)

Data in Table 5 can be analyzed to answer the hypothesis of main factors interaction toward the dependent variable with each interpretation. First, the interaction between learning methods toward learning outcomes shows the value of Sig. $=0.514>\alpha=0.05$ then H0 is accepted. It means that learning methods do not affect student-learning outcomes. Second, the interaction among gender factors shows the value of Sig. $=0.98>\alpha=0.05$, then $\mathrm{H} 0$ is accepted. Therefore, gender does not affect learning outcomes. Third, the interaction of motivation on learning outcomes shows the value of $\mathrm{Sig}=0.051>\alpha=0.05$, then $\mathrm{H} 0$ is accepted or the motivation factor does not affect learning outcomes. Fourth, the interaction between self-efficacy and learning outcomes shows the value of Sig. $=0.01<\alpha=0.05$, then $\mathrm{H} 0$ is rejected or self-efficacy factor influences students' mathematics learning outcomes. Furthermore, to find out which level/category, the researchers compare the marginal average. It is found that the average of self-efficacy is high (72.9063) more than the low efficacy average (68.0053). Therefore, it can be concluded that students' learning outcomes with high self-efficacy are better than students with low self-efficacy. Fifth, the data show that there is no interaction between the main factors (learning method, gender, motivation, and self-efficacy) towards the dependent variable, (learning outcomes). These results are relevant to the hypothesis results above where only factor D (self-efficacy) that has an effect on learning outcomes. The further analysis will be presented in this following description. 


\subsection{First Hypothesis}

Based on Table 5 on learning method factors, H0 is accepted because the value of Sig $>\alpha$, or $0.514>0.05$. It means that there is no significant difference in student learning outcomes between jigsaw cooperative learning methods and conventional methods. This result is supported by the Essays study on 2003. The results do not show the effectiveness of jigsaw method specifically. Jigsaw is only explained as one of many cooperative learning strategies that have demonstrated effectiveness, but it has weaknesses for students in general education and in special education. The implementation of jigsaw consists of some limitations. This relates to the teacher. The teachers' research shows that students knew jigsaw method, but in the implementation, they missed an important step to teach the material they were experts to other members of their group [24]. Therefore, the success of jigsaw depends on the teachers' ability in explaining how to apply the approach correctly or vice versa. It happens because cooperative learning is based on a constructivist approach that requires the use of experience-based activities This finding is different from Azmin (2016) that Jigsaw is beneficial for developing social skills. However, it was emphasized that, despite the positive findings obtained from this study, jigsaw method is only one of many cooperative learning methods and it is not a perfect teaching method [25]. This finding has theoretical and practical implications that the effectiveness of jigsaw cooperative learning methods specifically and cooperative learning methods generally are influenced by several factors, including the teachers' readiness in managing learning situations that support the learning process.

\subsection{Second Hypothesis}

The second hypothesis is related to gender factors. Based on table 5, there is no difference in student learning outcomes between male and female students because the value of Sig $>\alpha$, or $0.980>0.05$ or H0 is accepted. This result is supported by previous studies that there was no significant difference between male and female in mathematics [26], there was no statistically significant difference between students' science learning outcomes based on gender differences [27], there were no significant differences in learning results between male and female students even though the influence of culture is interesting to be studied further due to the assumption that male students are considered superior [28] while female students are superior in motivation, ability, performance, and self-management [29]. Glory's finding (2017) also shows that gender has a significant influence on interest but it does not have a significant influence on integrated science learning outcomes for students [30]. This result is different from Samuelsson's finding that compared to female, male students believe that mathematics is important [31]. In general, these findings have theoretical and practical implications for teachers to generate other factors related to gender and learning outcome.

\subsection{Third Hypothesis}

Based on table 5, there is no difference between the learning outcomes of students who have high and low motivation because the value of $\mathrm{Sig}>\alpha$, or $0.051>0.05$, so H0 is accepted. This result is different from Tella (2007). She says that students with high motivation have better academic performance than the students with low motivation [32]. In addition, the findings of Zamsir and Fajrin (2015) show that students' learning motivation has a positive influence on mathematics learning outcomes of junior high school students with $10 \%$ contribution [33]. While Ozen (2017) shows that motivation has a low positive effect on student outcomes [34].

Therefore, this research finding shows different results from the theory and results of previous studies. The differences in individual motivation above can be explained in relation to their mathematics teacher, that the intrinsic motivation in learning mathematics can be 
developed by considering the stimulation, control, and interest factors [35]. It implies that there are other variables or factors that can influence students learning motivation development, including math competition, parents, books, teachers at school [36]. Due to avoid the anxiety in completing mathematical tasks, [35] the students with high anxiety cannot develop their motivation. Therefore, the teacher must be patient, encourage, and support them based on their individual learning style. This is assumed that the motivation will have a positive effect on students 'mathematics learning outcomes based on the teacher's role in developing students' intrinsic motivation through appropriate instructional design.

\subsection{Fourth Hypothesis}

Based on table 5, there are differences in learning outcomes between students with high and low self-efficacy because the value of $\operatorname{Sig}<\alpha$, or $0.01<0.05$, then $\mathrm{H} 0$ is rejected. This is relevant to the previous research result that self-efficacy has high correlation to the value of mathematical outcomes [37], [38], [39]. However, other studies show that there is no significant difference between self-efficacy and mathematics learning outcomes in male and female students [26]. It implies that there are practical implications for teachers to focus on increasing self-efficacy related to mathematics learning outcomes [40] [41] through emphasizing students' selfconfidence to succeed in mathematics outcomes [26] because self-efficacy is positively related to mathematics learning outcomes [38].

\subsection{Fifth Hypothesis}

The fifth hypothesis states that there is an interaction between learning methods, gender, motivation, and self-efficacy towards learning outcomes. In general, this hypothesis is not proven because it is influenced by the results of hypotheses 1-3 where the main factors (learning methods, gender, and motivation) do not give different effects on student learning outcomes, especially in mathematics subjects. There is only self-efficacy that has a different effect on learning outcomes, but learning method and self-efficacy factors do not have correlation to learning outcomes. This result is relevant to the findings that jigsaw has no effect on selfefficacy perception [42]; there is no interaction between learning strategies (jigsaw and conventional) and learning motivation (high and low) [43]; there is no correlation between selfefficacy and learning outcomes in both male and female students [44]; there is no significant differences between gender differences and outcomes motivation [45]. Amedu (2015) shows that there is a significant difference between learning outcomes average based on gender by using Jigsaw [46]; Jigsaw has a significant influence on self-efficacy and learning motivation [47], and cooperative learning method is more effective than traditional method related to students achievement and attitude [48]. However, this evidence is not sufficient to support the interaction between main factors and dependent variable in this study based on the assumptions and explanations before. Therefore, this finding is different from the fifth hypothesis. It is assumed that this result is different from other researchers' result that will give theoretical and practical contribution.

\section{CONCLUSION}

This study aims to examine the use of 4 factors factorial design (learning methods, gender, motivation, and self-efficacy) on independent variables (learning outcomes) through experimental design. There are five hypotheses proposed to determine the effect of 4 factors interaction on dependent variable. The results of data analysis by using SPSS-assisted variant analysis show that there is no significant effect between learning method factors (first 
hypothesis), gender (second hypothesis), and motivation (third hypothesis) on mathematics learning outcomes. Only the fourth hypothesis (self-efficacy) is proven to give influences on learning outcomes in mathematics. This result gives influences on the fifth hypothesis, that there is no interaction between the main factors on the dependent variable. Empirically, this result is different from other researchers result because of other factors and variables that give influence on students' outcomes. The researchers cannot control those factors and variables. In general, the teacher's role factors related to skills in designing effective learning by considering students characteristics and the subject becomes one of important variable to be further studied. The development of teacher professionalism has to focus on the subject and teachers opportunity to continue learning by mixing the real experience using different curriculum and real assessment.

\section{REFERENCES}

[1] S. Suryabrata, "Metodologi penelitan, “ 2012.

[2] Kemdikbud, "Rekap hasil ujian nasional (UN) tingkat sekolah," 2017.

[3] A. D. Budiargo and R. S. Purwanti, "Upaya meningkatkan prestasi belajar IPS menggunakan model pembelajaran tipe course review horay pada kelas iv SD Muhammadiyah Sidoarum Godean Sleman tahun pelajaran 2013/2014,” 2015.

[4] Slameto, "Belajar dan faktor-faktor yang mempengaruhi: Edisi revisi," 2010.

[5] I. Mushtaq, and S. N. Khan, "Factors affecting students' academic performance," Global Journal of Management and Business Research., vol. 12, no. 9, 2012.

[6] S. Sirait, "Does teacher quality affect student achievement? An empirical study in Indonesia," Journal of Education and Practice., vol. 7, no. $27,2017$.

[7] R. H. Heck, "Teacher effectiveness and student achievement: Investigating a multilevel cross-classified model," Journal of Educational Administration., vol. 47, p. 227-249, 2009.

[8] S. E. Akpo, "The impact of teacher-related variables on students' Junior Secondary Certificate (JSC) mathematics results in Namibia," 2012.

[9] B. K. Hamre, R. C. Pianta, J. T. Downer, J. DeCoster, A. J. Mashburn, S. M. Jones, M. A. Brackett, "Teaching through interactions: Testing a developmental framework of teacher effectiveness in over 4,000 classrooms," The Elementary School Journal ., vol. 113, no. 3, p. 461-487, 2013.

[10] M. A. Kraft and S. Grace, "Teaching for tomorrow's economy? Teacher effects on complex cognitive skills and social-emotional competencies," 2016.

[11] D. Blazer and M. A. Kraft, "Teacher and teaching effects on students' attitudes and behaviors,"Educ Eval Policy Anal ., vol. 39, p. 146-170, 2016.

[12] L. V. Hedges and A. Nowell, "Sex differences in mental test scores, variability, and numbers of high-scoring individuals," Science., vol. 269, p. 41-45, 2015.

[13] M. J. Zembar, "Gender and academic achievement," 2017.

[14] H. F. Ladd, L. C. Sorensen, "Returns to teacher experience: Student achievement and motivation in middle school," Working Paper., no. 112, Washington, D C: National Center for Analysis of Longitudinal in Education Research), 2015.

[15] E. A. Ruzek, T. Domina, A. M. Conley, G. J. Duncan, S. A. Karabenick, "Using valueadded models to measure teacher effects on students' motivation and achievement," The Journal of Early Adolescence., vol. 35, p. 852-882, 2015.

[16] A. Bandura, C. Barbaranelli, G. V. Caprara, C. Pastorelli, "Multifaceted impact of selfefficacy beliefs on academic functioning," Child Development., vol. 67, no. 3, p. 12061222, 2012. 
[17] E. L. Usher, F. Pajares, "Sources of self-efficacy in school: Critical review of the literature and future directions," Review of Educational Research., vol. 78, no. 4, p. 751796, 2008.

[18] N. Kaura and R. Sharma, "The effect of gender on achievement motivation," Indian Journal of Health \& Wellbeing., vol. 6, no. 5, p. 504-507, 2015.

[19] K. L. Knight, "Study/Experimental/Research Design: Much More Than Statistics, “ Journal of Athletic Training., vol. 45, no. 1, p. 98-10, 2010.

[20] SAS , "Concepts of Experimental Design," 2015.

[21] H. White \& S. Sabarwal, "Quasi-experimental Design and Methods, Methodological Briefs: Impact Evaluation 8 (UNICEF Office of Research, Florence)," 2014.

[22] U. Tisngati, Martini, N. I. Meifiani, D. C. N. Cahyani, "Desain Faktorial 4 Faktor,” 2017.

[23] A. Bandura, "Self-efficacy The Exercise of control, " 1997

[24] U. K. Essays, "The effectiveness of the jigsaw approach," 2013.

[25] N. H. Azmin, "Effect of the jigsaw-based cooperative learning method on student performance in the general certificate of education advanced-level psychology: an exploratory brunei case study," International Education Studies., vol. 9, no. 1, 2016.

[26] A. Ayotolaa and T. Adedejib, "The relationship between mathematics self-efficacy and achievement in mathematics," Procedia - Social and Behavioral Science., vol. 1, p. $953-$ 957, 2009.

[27] J. O. Babalola and G. A. Fayombo, "Investigating the combined and relative effects of some student related variables on science achievement among secondary school students in Barbados," European Journal of Scientific Research., vol. 37, p. 481-489, 2009.

[28] U. J. Uduosoro, "The Effect of gender and mathematics ability on academic performance of students in chemistry," African Research Review., vol. 5, 2011.

[29] B. L. Hartley and R. M. Sutton, "A Stereotype threat account of boys' academic underachievement," Child Dev., vol. 84, no. 5, p. 1716-33, 2013.

[30] G. E. Glory, "Influence of gender on interest and academic achievement of students in integrated science in obio akpor local government area of rivers state,"European Scientific Journal., vol. 13, no. 10, 2017.

[31] M. Samuelsson and J. Samuelsson, “Gender Differences In Boys' And Girls' Perception Of Teaching And Learning Mathematics, “Open Review of Educational Research., vol 3 , no $1,2016$.

[32] A. Tella, "The impact of motivation on student's academic achievement and learning outcomes in mathematics among secondary school students in Nigeria," Eurasia Journal of Mathematics, Science \& Technology Education., vol. 3 , p.149-156, 2007.

[33] Zamsir, La Masi, Fajrin, "Pengaruh motivasi belajar terhadap hasil belajar matematika siswa SMPN 1 Lawa," Jurnal Pendidikan Matematika., vol. 6, 2015.

[34] S. O. Özen, "The Effect of motivation on student achievement (the factors effecting student achievement: meta-analysis of empirical studies by Engin Karadag, Springer International Publishing), 2017

[35] J. A. Middleton and P. A. Spanias, "Motivation for achievement in mathematics: findings, generalizations, and criticisms of the research," Journal for Research in Mathematics Education., vol. 30, p. 65-88, 1999.

[36] G. Dimakos, I. Tyrlis I, and F. Spyros, "Factors that influence students to do mathematics," The Teaching of Mathematic., vol. 15, p. 43-54, 2012.

[37] D. L. A. Situmorang, "Pengaruh model pembelajaran dan self-efficacy terhadap hasil belajar siswa SMA kelas X pada materi ekosistem di SMA Swasta Methodist 1 Medan ," Masters thesis, Medan: Medan University, 2013. 
[38] X. Liu and H. Koirala, "The effect of mathematics self-efficacy on mathematics achievement of high school students," NERA Conference Proceedings., vol. 30, 2009.

[39] C. W. Loo and J. L. F. Choy, "Sources of self-efficacy influencing academic performance of engineering students," American Journal of Educational Research., vol. 1, no. 3, p. 86-92, 2013.

[40] A. Kitsantas, J. Cheema \& H. W. Ware, "Mathematics achievement: The role of homework and self-efficacy beliefs," Journal of Advanced Academics., vol. 22, no. 2, p. 310-339, 2011.

[41] C. M. Aurah and T. J. McConnell, "Comparative study on pre-service science teachers' self-efficacy beliefs of teaching in Kenya and the United States of America," American Journal of Educational Research., vol. 2, no. 4, p. 233-239, 2014.

[42] S. Sengul and Y. Katranci, "Effects of jigsaw technique on mathematics self-efficacy perceptions of seventh grade primary school students," Procedia - Social and Behavioral Sciences, 33 - 338 (5th World Conference on Educational Sciences - WCES 2013). 2014

[43] R. Rasyidin, M. S. Ikbal and S. Sulasteri, "Pengaruh strategi pembelajaran kooperatif tipe jigsaw terhadap hasil belajar fisika ditinjau dari motivasi belajar pada pelajaran fisika," Jurnal Pendidikan Fisika., vol. 4, 2016.

[44] H. Miranti, "Hubungan self-efficacy berdasarkan gender dengan hasil belajar siswa pada mata pelajaran IPA kelas VIII SMP se-kecamatan Teluk Betung Selatan tahun ajaran 2015/2016," 2016.

[45] N. Kaura and R. Sharma, "The effect of gender on achievement motivation," Indian Journal of Health \& Wellbeing., vo. 6, no. 5, p. 504-507, 2015.

[46] O. I. Amedu, "Effect of gender on the achievement of students in biology using the jigsaw method," Journal of Education and Practice., vol. 6, no. 17), p. 176-180, 2015.

[47] D. N. Rachmah, "Effects of jigsaw learning method on students' self-efficacy and motivation to learn," Journal of Educational, Health and Community Psychology., vol. 6, no. 3, p. 1-9, 2017. 